\title{
AFETOS, REPRESENTAÇÕES E PSICOPATOLOGIAS: DA ANGÚSTIA AO PÂNICO
}

\author{
Carlos Eduardo de Sousa Lyra
}

A pesquisa visa contribuir para o estudo das psicopatologias ditas "contemporâneas", em especial para o conhecimento da psicodinâmica do transtorno de pânico, o qual é comparado ao quadro psicopatológico freudiano de "neurose de angústia”. Por outro lado, este trabalho também pretende oferecer uma revisão sistemática de alguns dos conceitos fundamentais da metapsicologia freudiana, acrescentando ao corpo teórico da metapsicologia desenvolvimentos realizados por teóricos pós-freudianos.

\section{BANCA:}

Ana Maria Rudge (Orientadora)

Ary Band

Benilton Bezerra Junior

Data de defesa: 5/11/2007 